\title{
Quality characteristics of pelleted compound feeds under varying storage conditions as influenced by purity and concentration of glycerol from biodiesel production*
}

\author{
K.-H. Südekum ${ }^{1,3,5}$, A. Schröder ${ }^{1,4}$, S. Fiebelkorn ${ }^{1}$, R. Schwer ${ }^{1}$ \\ and A. Thalmann ${ }^{2}$ \\ ${ }^{1}$ Institut für Tierernährung und Stoffwechselphysiologie, Christian-Albrechts-Universität \\ 24098 Kiel, Germany \\ ${ }^{2}$ Staatliche Landwirtschaftliche Untersuchungs- und Forschungsanstalt Augustenberg \\ Postfach 4302 30, 76217 Karlsruhe, Germany
}

(Received 30 April 2007; revised version 6 November 2007; accepted 15 January 2008)

\begin{abstract}
The effects of concentrates, in which glycerol plus soyabean meal replaced wheat, on physical, chemical and hygienic pellet quality characteristics were investigated. Three purities of glycerol were used, reflecting different stages of the biodiesel production process. Glycerol inclusion levels were 50,100 and $150 \mathrm{~g} / \mathrm{kg}$ concentrate dry matter (DM). Concentrates were stored under good $\left(15^{\circ} \mathrm{C}, 60 \%\right.$ relative humidity) or bad $\left(20^{\circ} \mathrm{C}, 70 \%\right.$ relative humidity) environmental conditions and for 4 or 8 weeks. Chemical quality was only slightly affected by purity and concentration of glycerol and likewise by storage conditions or duration. Ergosterol concentration indicated that glycerol of different purity had a preserving effect. The physical quality of pellets was not affected by the purity of glycerol or by glycerol concentration of up to $150 \mathrm{~g} / \mathrm{kg} \mathrm{DM}$. Glycerol at different purity may help to stabilize the hygienic quality of pelleted compound feeds without compromising the physical quality of pellets.
\end{abstract}

KEY WORDS: pelleting, pellet quality, glycerol, storage, ergosterol

\footnotetext{
"Supported in part by the "Deutsche Forschungsgemeinschaft", DFG, German Research Foundation; Habilitandenstipendium SCHR 551/1-1 and 1-2

${ }^{3}$ Present address: Institute of Animal Science, Animal Nutrition Group, University of Bonn, Endenicher Allee 15, 53115 Bonn, Germany

${ }^{4}$ Present address: Dr. Pieper Technologie- und Produktentwicklung GmbH, Dorfstraße 34, 16818 Wuthenow, Germany

${ }^{5}$ Corresponding author: e-mail: ksue@itw.uni-bonn.de
} 


\section{INTRODUCTION}

The turn towards renewable energy sources in the European Union has increased the production of biofuel from rape seed oil, mainly in the form of rape seed oil methylester (RME) or biodiesel, leaving glycerol as a by-product (Körbitz et al., 2003). If the amount of glycerol from biodiesel production exceeds the needs of pharmaceutical and chemical industries, it could be used in animal nutrition, possibly in the form of less pure and thus cheaper qualities. Glycerol was registered as a feed additive (E 422) in the European Union more than 30 years ago (Anonymous, 1970 ) with no restrictions as to animal species and quantity added to feeds. Recently, and at least in part as a result of increasing biodiesel production and thus glycerol accumulation, glycerol was listed as a feedstuff in the "Positive List" of authorized feed materials (Normenkommission für Einzelfuttermittel im Zentralausschuss der Deutschen Landwirtschaft, 2007) which, among other objectives, was initiated to contribute to feed safety internationally (Anonymous, 1996) and nationally (Petersen and Flachowsky, 2004).

In past decades, pelleting of feeds has become a firmly established process within the feed industry, because pellets offer numerous advantages compared with meals: improved flow properties in conveying equipment and silos, increased bulk density, dust binding, no segregation of components and reduced feed refusals (Rumpf, 1962). The quality of pellets depends markedly on external factors like storage and technology, as well as on the proportion and physical and chemical properties of raw materials, with a particular role of feed additives like pellet binders or stabilizers (for review, see Thomas and van der Poel, 1996; Thomas et al., 1997, 1998). Due to its hygroscopicity, glycerol can affect the quality of compound feed pellets, because general binding forces of feed particles and water activity in the feedstuffs may be influenced. Therefore glycerol may influence physical, chemical and hygienic variables of feedstuffs. However, it is not clear under which conditions glycerol may result in either improvement or detriment of pellet quality.

The objectives of this study were to evaluate the physical, chemical and hygienic properties of pelleted compound feeds containing glycerol of different purity and at different concentrations. Feeds were stored under different environmental conditions reflecting a range of situations that will also occur in practice.

\section{MATERIAL AND METHODS}

\section{Experimental design}

The experiment was conducted as a completely randomized design, with a $10 \times 5$ factorial ( 10 concentrates and 5 storage conditions) arrangement of treatments, totalling 
50 treatments. Each treatment was replicated 3 times, with a total of 150 experimental units. The ten concentrates resulted from one concentrate without glycerol (Control) and three glycerol concentrations (50, 100 and $150 \mathrm{~g} / \mathrm{kg}$ dry matter (DM)), each combined with glycerol of three purities (low, medium, high). Environments were defined by an unstored control and two storage conditions, hereafter designated good $\left(15^{\circ} \mathrm{C}, 60 \%\right.$ relative humidity $)$ and bad $\left(20^{\circ} \mathrm{C}, 70 \%\right.$ relative humidity), each combined with two storage durations, namely four and eight weeks. Three coarsely meshed jute sacks that allowed widely unrestricted air exchange between pellets and ambient air were used for each combination of factors. Sacks were filled with $2 \mathrm{~kg}$ pelleted feed.

\section{Purity of glycerol and feed composition}

One ingredient of the compound feeds, designated concentrates hereafter, was glycerol of low, medium or high purity (glycerol concentration approximately 600,800 or $1000 \mathrm{~g} / \mathrm{kg}$ product), reflecting different stages of the same process of RME production (Ölmühle GesmbH, Bruck/Leitha, Austria). The chemical composition of the three glycerol types is shown in Table 1. Major differences between the glycerols were observed in concentrations of water, glycerol,

Table 1. Chemical composition of glycerol of different purities ${ }^{1}$

\begin{tabular}{lccc}
\hline & \multicolumn{3}{c}{ Purity of glycerol } \\
\cline { 2 - 4 } Water, g/kg & low & medium & high \\
\cline { 2 - 4 } Dry matter composition, $\mathrm{g} / \mathrm{kg}$ unless stated & 11.0 & 25.0 \\
glycerol & 633.0 & & \\
crude fat & 7.1 & 853.0 & 998.0 \\
phosphorus & 10.5 & 4.4 & $\mathrm{NA}^{2}$ \\
potassium & 22.0 & 23.6 & $\mathrm{NA}$ \\
sodium & 1.1 & 23.3 & $\mathrm{NA}$ \\
lead, mg/kg & 3.0 & 0.9 & $\mathrm{NA}$ \\
methanol & 267.0 & 2.0 & $\mathrm{NA}$ \\
\hline
\end{tabular}

${ }^{1}$ samples were analysed in triplicate

${ }^{2} \mathrm{NA}$, not analysed; analyses were omitted because the glycerol content was close to $1000 \mathrm{~g} / \mathrm{kg}$ and high purity glycerol is listed in the official European Union and United States pharmacopoeias

phosphorus, and methanol. In order to use some of the concentrates investigated in concurrent animal studies on cattle and sheep (Schröder and Südekum, 1996, 1999), concentrates were formulated on an isonitrogenous and isocaloric (net energy for lactation) basis. Ten concentrates were produced, one batch of each, formulated to contain no glycerol, or 50,100 or $150 \mathrm{~g} / \mathrm{kg}$ DM of glycerol from the above mentioned types of glycerol. The ingredient composition of the different concentrates is presented in Table 2 . 
Table 2. Ingredient composition ( $\mathrm{g} / \mathrm{kg}$ dry matter) of pelleted concentrates containing no glycerol (Control) or glycerol of different purities ${ }^{1}$ at three different concentrations ${ }^{2}$

\begin{tabular}{|c|c|c|c|c|c|c|c|c|c|c|}
\hline \multirow{3}{*}{ Ingredient } & \multirow{3}{*}{$\begin{array}{c}\text { Control } \\
0\end{array}$} & \multicolumn{9}{|c|}{ Purity of glycerol } \\
\hline & & \multicolumn{3}{|c|}{ low } & \multicolumn{3}{|c|}{ medium } & \multicolumn{3}{|c|}{ high } \\
\hline & & 50 & 100 & 150 & 50 & 100 & 150 & 50 & 100 & 150 \\
\hline Wheat, ground & 300 & 230 & 160 & 100 & 230 & 160 & 100 & 230 & 160 & 100 \\
\hline $\begin{array}{l}\text { Sugar beet pulp, } \\
\text { dehydrated }\end{array}$ & 200 & 200 & 200 & 200 & 200 & 200 & 200 & 200 & 200 & 200 \\
\hline Wheat bran & 140 & 140 & 140 & 140 & 140 & 140 & 140 & 140 & 140 & 140 \\
\hline Rapeseed meal & 120 & 120 & 120 & 120 & 120 & 120 & 120 & 120 & 120 & 120 \\
\hline Soyabean meal & 100 & 120 & 140 & 150 & 120 & 140 & 150 & 120 & 140 & 150 \\
\hline Maize & 100 & 100 & 100 & 100 & 100 & 100 & 100 & 100 & 100 & 100 \\
\hline Premix $^{3}$ & 40 & 40 & 40 & 40 & 40 & 40 & 40 & 40 & 40 & 40 \\
\hline Glycerol & 0 & 50 & 100 & 150 & 50 & 100 & 150 & 50 & 100 & 150 \\
\hline
\end{tabular}

${ }^{1}$ for details of glycerols, see Table 1

${ }^{2}$ values are based on dry matter analyses on ingredients and weighed amounts of ingredients before feed mixing

${ }^{3}$ mineral vitamin mixture, pellet binder (Diamol ${ }^{\circledR}$; Franz Bertram, Hamburg, Germany) and titanium(IV)-oxide

\section{Processing}

Concentrates were processed with a $20 \mathrm{~kW}$ hammer mill (Wachtel, Reinbek, Germany), equipped with a 3-mm screen, a horizontal batch mixer (ploughshare ${ }^{\circledR}$ mixer FM 130; Lödige, Paderborn, Germany) with a capacity of $90 \mathrm{~kg}$ and an $11 \mathrm{~kW}$ pellet press (Simon-Heesen, Boxtel, Netherlands). All ingredients except premix and glycerol were ground in a hammer mill, weighed and put into the mixer. Concentrates were mixed in batches of $50 \mathrm{~kg}$. First, the premix was mixed in the horizontal batch mixer, then grains and by-products were added, and finally glycerol was supplemented directly into the mixer. The pellet press consisted of a static die and three rotating rollers. The die size, described by length to diameter ratio (mm:mm) of bore holes, was 40:6. To achieve pellets of the best possible quality, water was added to glycerols of medium and high purity, and the gap-size between roller and die as well as the distance between the pellet die knife and the die face were adjusted as necessary. In order to decrease moisture subsequent to the pelleting process, pellets passed a vibratory cooler (DK-60; Simon-Heesen, Boxtel, Netherlands) at a rate of approximately $2.5 \mathrm{~kg} / \mathrm{min}$ and a temperature of $30^{\circ} \mathrm{C}$.

\section{Pellet quality}

The hardness of the pellets was measured using a hardness tester (PTB 301/501; Pharma Test, Hainburg, Germany). The pellets were conditioned overnight at $50^{\circ} \mathrm{C}$ and randomly chosen to insert them singly between two bars. By increasing static 
pressure applied by means of a spring, the force (newton [N]) needed to crack the pellet was recorded by a force transducer. The average of ten measurements is referred to as the hardness of the pellets.

Durability of pellets was estimated from particle size distribution of a batch of pellets. Fines were induced by an abrasing action of pellets shearing over each other and over the wall and ledges of drums in a tumbling device with four chambers and a circumference of the drum of $138 \mathrm{~cm}$, as described by Scholz (1976). Pellets were conditioned at $30^{\circ} \mathrm{C}$ overnight; then $500 \mathrm{~g}$ of pellets free of abrasion were inserted into each chamber of the drum. A haulage way of 500 $\mathrm{m}$ was simulated by 360 rotations of the tumbling can device at 36 rotations per min. Finally pellets were sieved with an electromagnetic sieve shaker (Vibratronic VE-1; Retsch, Haan, Germany) using sieves with square openings of 4.75 and $2.00 \mathrm{~mm}$. The sieve shaker was operated at an amplitude of $0.7 \mathrm{~mm}$ for $4 \mathrm{~min}$. Vibrations were interrupted for about $2 \mathrm{sec}$ every $20 \mathrm{sec}$. The proportion of total sample retained on the $4.75 \mathrm{~mm}$ sieve, i.e. $0.8 \times$ pellet diameter, was considered whole pellets; the respective proportion of the sample retained on the sieve with $2.00 \mathrm{~mm}$ openings was denoted as broken pellets, and all material that could pass this sieve size was designated as fines.

\section{Sample processing and analytical procedures}

Pellets were successively ground in mills with 3 and $1 \mathrm{~mm}$ screens and, for starch analysis, with a $0.2 \mathrm{~mm}$ screen. The DM of pellets from each jute sack was estimated by oven-drying at $105^{\circ} \mathrm{C}$ overnight. Ash was determined by ashing in a muffle furnace at $550^{\circ} \mathrm{C}$ overnight $(16 \mathrm{~h})$. Ether extract (petroleum ether extract after acid hydrolysis by the Soxhlet method; method 5.1.1) and crude fibre (method 6.1.4) were analysed according to "Verband Deutscher Landwirtschaftlicher Untersuchungs- und Forschungsanstalten" (VDLUFA; Bassler, 1988, 1993). N was determined using a standard Kjeldahl procedure using $\mathrm{Cu}^{2+}$ as a catalyst (method 4.1.1; Bassler, 1988, 1993) and crude protein $(\mathrm{CP})$ calculated as $(\mathrm{N} \times 6.25)$. Starch was quantified after enzymatic hydrolysis of starch to glucose as described by Brandt et al. (1987). Ergosterol was analysed by liquid chromotography (Schwadorf and Müller, 1989) and used as an indicator for fungal biomass. Glycerol determination in pellets started with dispersing $5 \mathrm{~g}$ of finely ground ( $1 \mathrm{~mm}$ screen) material or $5 \mathrm{~g}$ of one of the three glycerol commodities with $100 \mathrm{ml}$ of double-distilled water in a shaking water-bath at $80^{\circ} \mathrm{C}$ for $15 \mathrm{~min}$. Then the extract was separated by filtering and glycerol was analysed enzymatically (Glycerol UV Method, catalogue number 148270; Boehringer Mannheim, Mannheim, Germany). The water content of the different glycerol types was determined using an automatic Karl Fischer titrator (Karl FischerTitrator E 551; Metrohm, Herisau, Switzerland), dispensing Karl Fischer reagents 
(Volumetry-Two-Component Reagents [number 34800 and 34801]; Riedel-de Häen, Seelze, Germany) from a Metrohm Dosimat (E 415, Herisau, Switzerland). The DM content $(\mathrm{g} / \mathrm{kg})$ of glycerol was estimated as 1000 minus water. Methanol was analysed using an HPLC method (Siegfried et al., 1984) that is routinely used for monitoring silage fermentation products including alcohols.

\section{Statistical analysis}

Data analysis was performed using the general linear models (GLM) procedure of SAS (1988). The model was as follows:

$$
\begin{array}{r}
\mathrm{y}_{\mathrm{jk}}=\mu+\text { concentrate type }_{\mathrm{j}}+\text { environment }_{\mathrm{k}}+(\text { concentrate type } \\
\times{\text { environment })_{\mathrm{jk}}+\varepsilon_{\mathrm{jk}}}
\end{array}
$$

where: $\mathrm{y}_{\mathrm{jk}}=$ observed response, $\mu=$ overall mean, concentrate type ${ }_{\mathrm{j}}=$ effect of concentrate type 1 to 10 , as outlined in material and methods, environment $t_{k}=$ effect of environment 1 to 5 , as outlined in material and methods; (concentrate type $\times$ environment $)_{j \mathrm{k}}=$ effect of interaction term of concentrate type ${ }_{\mathrm{j}}$ and environment $\mathrm{k}_{\mathrm{k}}$ and $\varepsilon_{\mathrm{jk}}=$ residual error.

Effects of pellet environment were further separated into linear contrasts. Contrasts were 'unstored vs stored', 'stored 4 weeks vs stored 8 weeks' and 'good vs bad storage conditions'. Further, effects within concentrate types were evaluated by the contrast 'unstored vs stored' (Table 7). Significance was declared at $\mathrm{P}<0.05$ unless otherwise stated. Values are presented as means with their respective SEM.

\section{RESULTS}

The chemical composition of the ten unstored concentrates is summarised in Table 3. Because concentrates where formulated to be isocaloric and isonitrogenous, concentrations of starch and glycerol varied, whereas CP concentrations were similar. Actual glycerol concentrations were close to the intended level indicating that preparation of the pellets matched the objectives. Although the methanol concentration of the glycerol of low purity was marked, only negligible quantities of methanol were detected in the pellets (data not shown).

Storage per se and storage duration or conditions did not appear to affect chemical composition of the concentrates and mainly reflected intended differences as observed for unstored concentrates. To quote an example, variation of CP concentration was small and the difference between extreme values was only $15 \mathrm{~g} / \mathrm{kg}$ DM (data not shown). Therefore, only data for DM are presented hereafter. 


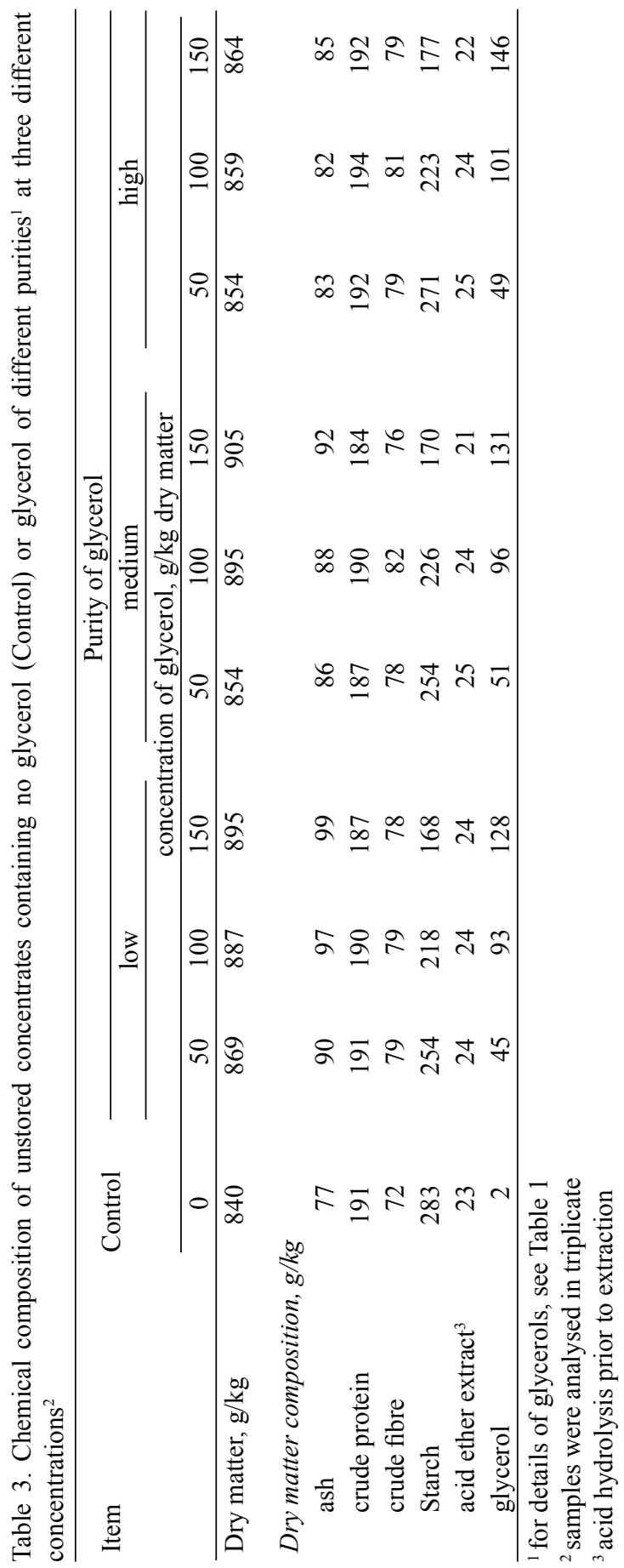


SÜDEKUM K.-H. ET AL.

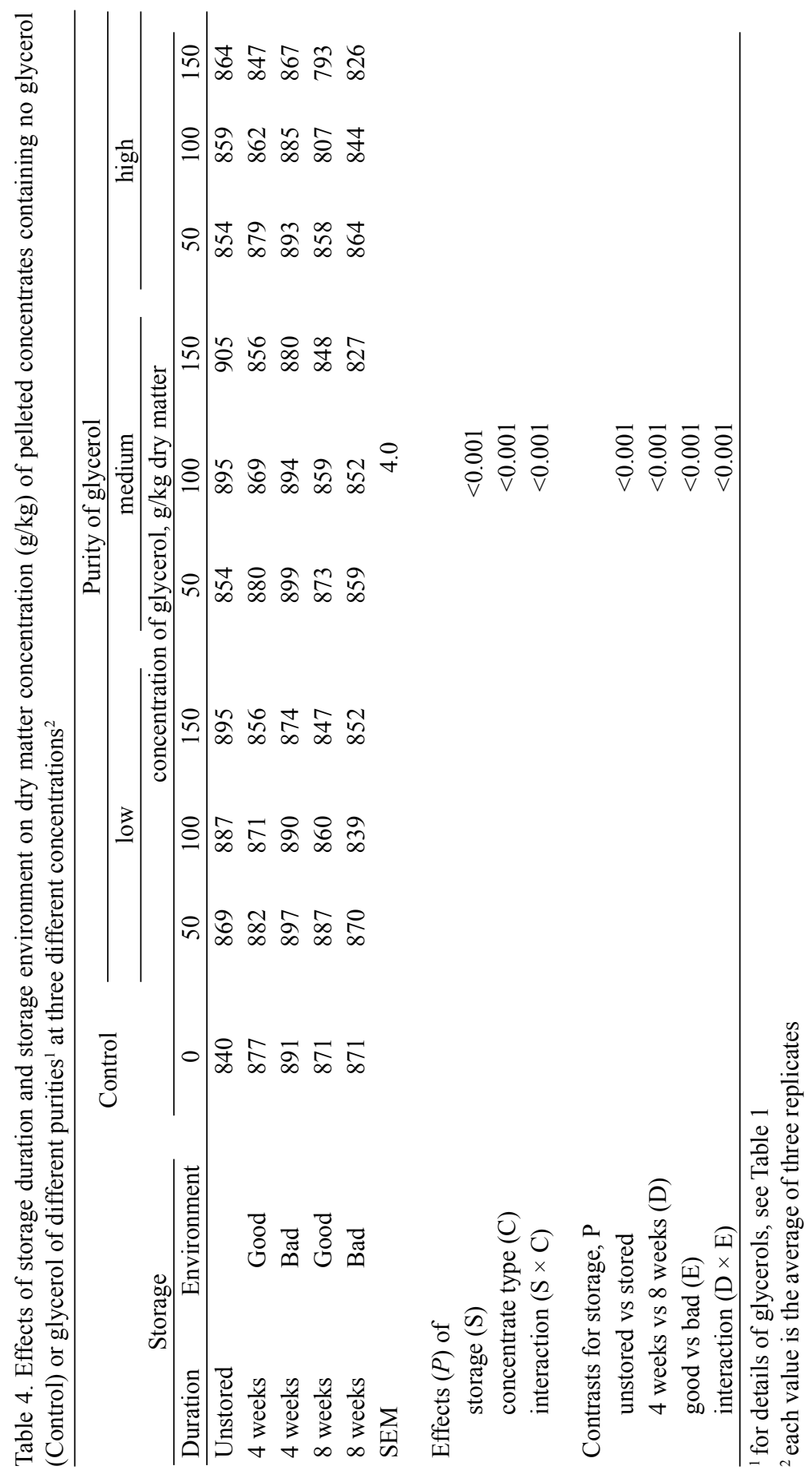




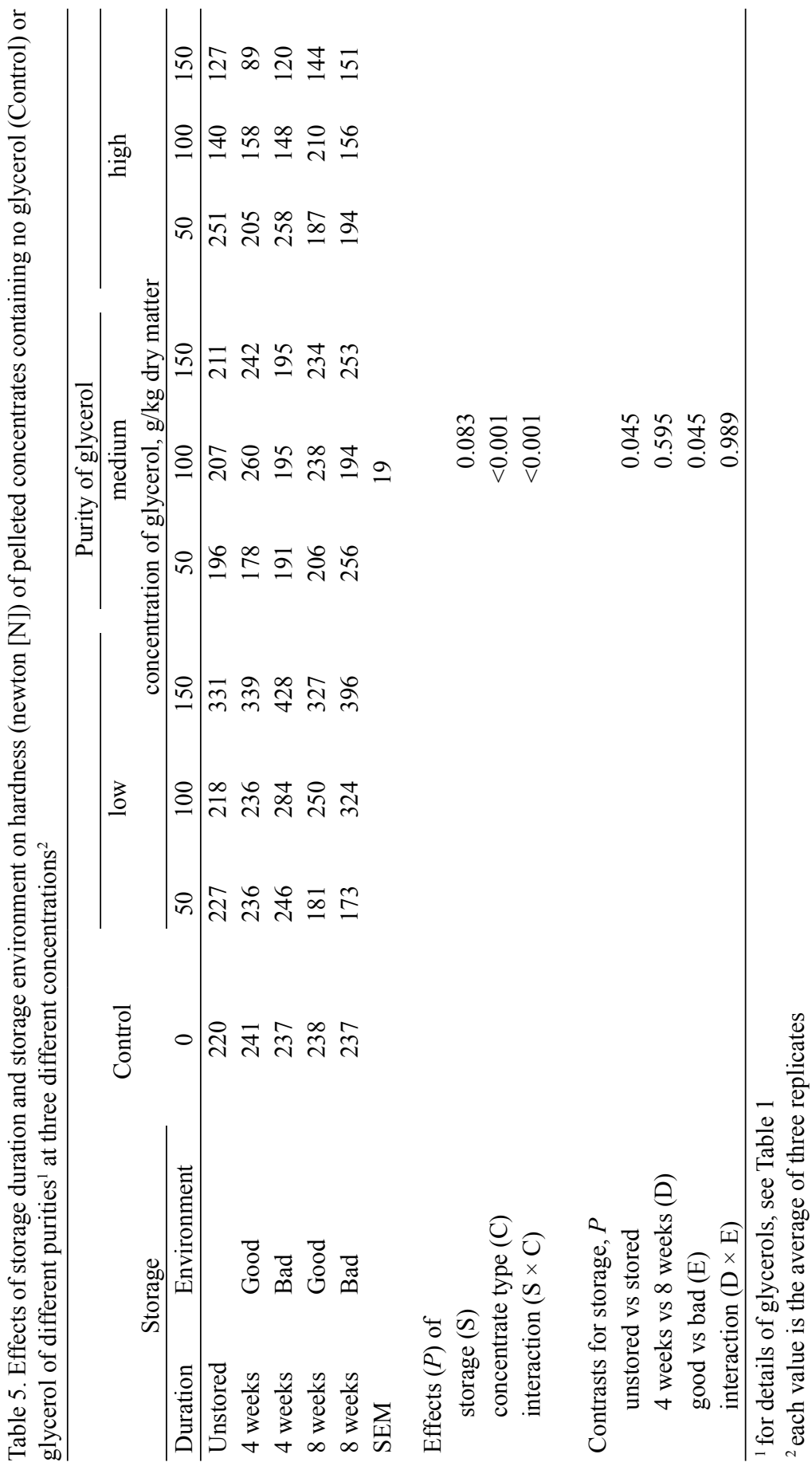


SÜDEKUM K.-H. ET AL.

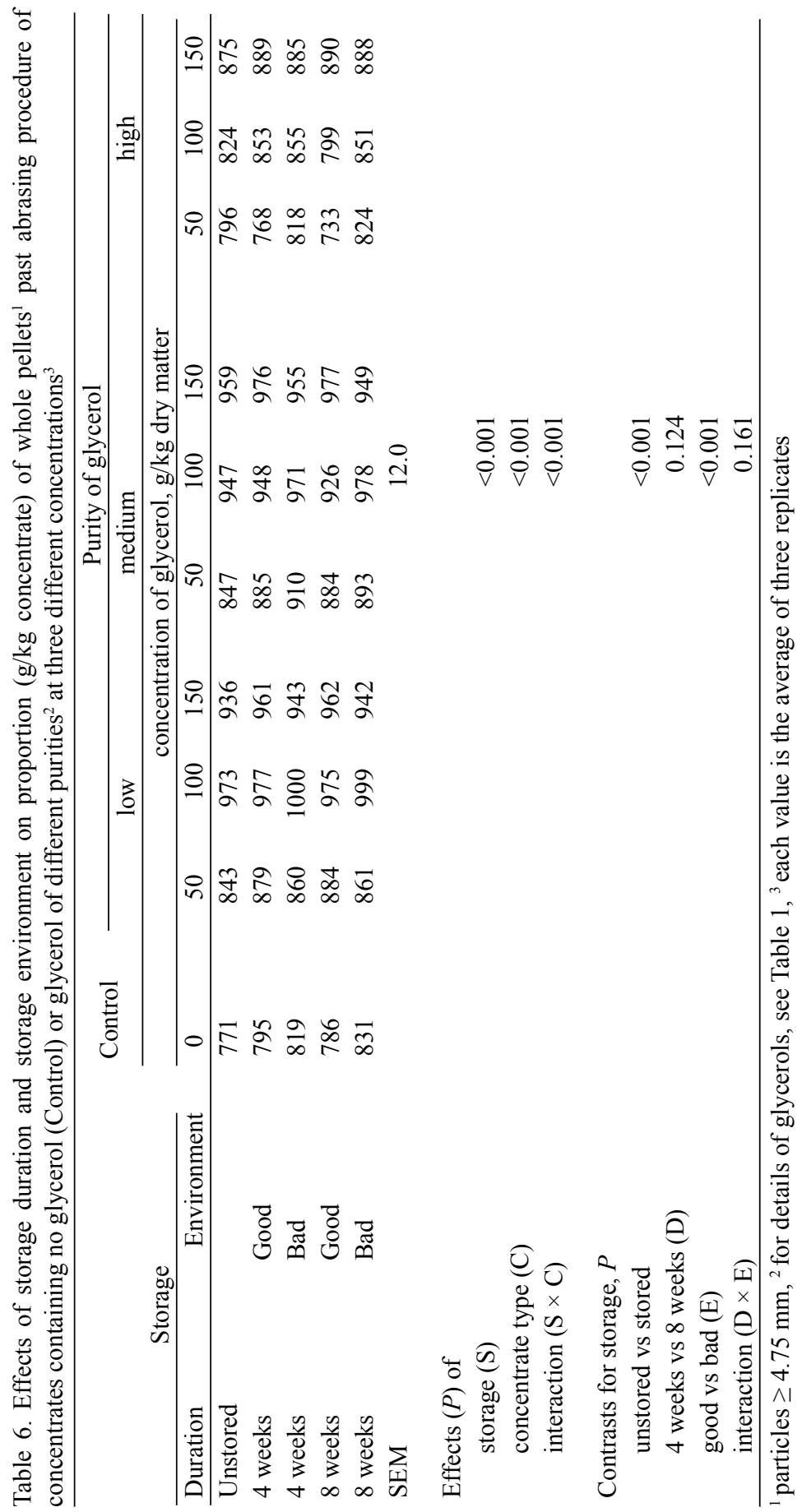


The DM concentration of unstored concentrates varied from $840 \mathrm{~g} / \mathrm{kg}$ for the control to $905 \mathrm{~g} / \mathrm{kg}$ for the concentrate with $150 \mathrm{~g} / \mathrm{kg}$ DM medium-purity glycerol (Table 4). Within glycerol purity, DM increased with increasing concentration of glycerol. Unlike unstored concentrates, the stored concentrates contained less DM, or more moisture, with increasing concentrations of glycerol. Significant effects were observed of storage and concentrate type and their interaction. The contrasts for storage revealed differences $(\mathrm{P}<0.001)$ between unstored and stored concentrates, between 4 and 8 weeks of storage, and between good and bad environments. Longer storage and bad storage conditions reduced DM and thus increased moisture contents of the pellets.

Unstored concentrates had 2.9 to $3.4 \mathrm{mg} / \mathrm{kg} \mathrm{DM}$ of ergosterol (data not shown). Only after the concentrate without glycerol (Control) had been stored for 8 weeks, a sharp increase of ergosterol (11.4 mg/kg DM) concentration was detected. This value was considerably higher than in all other stored materials, which ranged only from 1.7 to $3.4 \mathrm{mg} / \mathrm{kg}$ DM of ergosterol, thus resembling values of unstored pellets.

Hardness of unstored concentrates ranged from 127 to $331 \mathrm{~N}$. The lowest values were observed for concentrates with 100 and $150 \mathrm{~g} / \mathrm{kg} \mathrm{DM}$ of high-purity glycerol, pellets of the control had medium hardness and the greatest values were associated with the pellets containing $150 \mathrm{~g} / \mathrm{kg}$ DM low-purity glycerol (Table 5). This ranking was the same for all stored concentrates regardless of storage duration and condition. Effect of concentrate type on hardness was significant $(\mathrm{P}<0.001)$ and approached significance $(\mathrm{P}=0.083)$ for an effect of storage environment. As stated by contrasts for storage, duration (4 weeks vs 8 weeks) did not cause differences, whereas storage per se (unstored vs stored) led to an increase of pellet hardness. No interactions were observed between storage duration and conditions.

Particle size distribution of pelleted concentrates as indicated by the proportion of whole pellets is presented in Table 6. The unstored concentrates had 771 to 973 $\mathrm{g} / \mathrm{kg}$ of whole pellets. The lowest value was recorded for the control, and the highest value for the pellets with $100 \mathrm{~g} / \mathrm{kg} \mathrm{DM}$ of low-purity glycerol. Effects $(\mathrm{P}<0.001)$ were observed on proportion of whole pellets of storage and concentrate type as well as an interaction between these effects. The contrasts for storage showed marked effects $(\mathrm{P}<0.001)$ of storage per se (unstored vs stored) and of storage conditions (good vs bad). Change of proportion of whole pellets inevitably led to a change of proportion of other fractions, namely broken pellets and fines (data not shown).

The comparison of unstored and stored products within concentrate type, as presented in Table 7 clearly shows the effects of concentrate type on DM contents and physical pellet quality. DM contents of all types of concentrates were significantly altered by storage. While particle size distribution of pellets without glycerol (Control), with 50 and $100 \mathrm{~g} / \mathrm{kg}$ DM of glycerol, and of types with low and medium purity was affected by storage, no effects were observed for concentrate types with either $150 \mathrm{~g} / \mathrm{kg}$ DM glycerol or high purity glycerol. These effects were 
related to hardness of pellets. However, the most pronounced effects on hardness were found for concentrate types with glycerol at either $100 \mathrm{~g} / \mathrm{kg}$ DM or of low purity at all concentrations.

Table 7. Contrasts (P values) for unstored versus stored concentrates within concentrate type for dry matter concentration $(\mathrm{g} / \mathrm{kg})$ and physical pellet properties

\begin{tabular}{|c|c|c|c|c|c|c|c|}
\hline \multirow{3}{*}{ Item } & \multicolumn{7}{|c|}{ Concentrate type } \\
\hline & \multicolumn{4}{|c|}{$\begin{array}{l}\text { concentration of glycerol, } \mathrm{g} / \mathrm{kg} \text { dry } \\
\text { matter }\end{array}$} & \multicolumn{3}{|c|}{ Purity of glycerol ${ }^{1}$} \\
\hline & 0 & 50 & 100 & 150 & low & medium & high \\
\hline Dry matter & $<0.001$ & $<0.001$ & $<0.001$ & $<0.001$ & $<0.001$ & $<0.001$ & 0.013 \\
\hline Hardness & 0.386 & 0.211 & 0.007 & 0.093 & 0.028 & 0.192 & 0.730 \\
\hline $\begin{array}{l}\text { Particle size } \\
\text { distribution }^{2}\end{array}$ & & & & & & & \\
\hline whole pellets & 0.007 & 0.007 & 0.080 & 0.149 & 0.011 & 0.011 & 0.439 \\
\hline
\end{tabular}

${ }^{1}$ for details of glycerols, see Table $1,{ }^{2}$ whole pellets: $\geq 4.75 \mathrm{~mm}$

\section{DISCUSSION}

The magnitude of the changes of chemical composition caused by storage duration and condition was always small. These observations upon effects of storage on chemical composition of the pelleted concentrates are in line with findings on the hygienic quality of the pellets. Significant modifications of chemical composition during storage would have indicated enhanced microbial activity and growth, paralleled by an increase in microbial and, particularly fungal, biomass for which ergosterol has been used as a chemical marker in cereal grains and grain by-products (Müller and Lehn, 1988; Müller et al., 1994) and compound feeds (Bailly et al., 1999). The vast majority of ergosterol concentration was considerably lower than 'preliminary normal ranges' for these types of feeds $(6.1$ to $6.6 \mathrm{mg} / \mathrm{kg}$; calculated according to Müller and Schwadorf, 1988, 1990), therefore indicating products of excellent hygienic quality. Only eight weeks of storage of the control concentrate under bad conditions increased ergosterol concentration drastically $(11.4 \mathrm{mg} / \mathrm{kg}$ ), but still chemical composition was only modified slightly. Thus, storage longer than eight weeks or more sensitive analytical measures seem to be necessary to monitor chemical changes due to fungal activity and growth on the types of feeds studied here. It should not be overlooked that elevated ergosterol concentration is also a warning sign of possible mycotoxin contamination by moulds (Müller and Schwadorf, 1988).

In summary, it can be ascertained that glycerol of different purity and even at relatively low concentration $(50 \mathrm{~g} / \mathrm{kg} \mathrm{DM})$ had a preserving effect, likely caused 
by the hygroscopicity of glycerol, which decreases water activity and thus, water availability to (undesirable) microorganisms in the pellets (Heiss and Eichner, 1994). This preserving effect of glycerol is widely used in the food industry (Baltes, 1995). An interesting aspect of glycerol's impact on microbial activity was reported by Roger et al. (1992). These authors found that in vitro, glycerol at a concentration of $50 \mathrm{~g} / \mathrm{kg}$ in the incubation medium totally inhibited the cellulolytic activity of a strictly anaerobic rumen fungal species, Neocallimastix frontalis. This effect was probably caused in part by the inhibition of its growth, but the authors also discussed a possible effect on fungal cellulases.

The pellets investigated here were manufactured under conditions where process variables during pelleting could not be generally adjusted, because both concentration and purity of glycerol had an impact on the pellet production process. In order to produce unstored pellets of the best possible similarity in physical quality variables, it was necessary to adjust the pelleting process intuitively according to visual pellet appraisal by an experienced operator.

Hardness is an important quality characteristic for resistance of pellets to compressive forces during handling and storage. Values for durability and hardness are strongly dependent on devices and conditions used for their determination (Thomas and van der Poel, 1996). Therefore, only results derived from the same device can be reliably compared. No values have been reported so far using the same hardness assessment procedure as in this study, probably because this equipment is used more frequently in the pharmaceutical industry to evaluate tablet hardness. Moreover and unfortunately, abrasion devices in the feed industry are not internationally standardized and several types of equipment are available. Nevertheless, evaluation and comparison of the hardness and durability of concentrates of the present study should allow a relative ranking of treatments as related to different concentrations and purities of glycerol and to different storage durations and conditions.

The mechanisms of binding during pelleting are based upon natural adhesion between particles and the mechanical load which forces inter-particle contact. As already formulated almost 50 years ago by Rumpf (1958) and fully developed by Friedrich (1964) and Friedrich and Robohm (1968), various binding phenomena occur (recent reviews by Thomas and van der Poel, 1996 and Tabil et al., 1997): a. solid-solid interactions; b. capillary pressure and interfacial forces resulting in so-called 'liquid neckings'; c. adhesive and cohesive forces between particles and binders; $d$. interactions between particles due to folding and plying, and e. formclosed bonds or interlocking occurring in fibres, flattened or bulky particles. In our study, the most causative factors for expected differences of physical pellet quality variables would be 'stick' and hygroscopicity of glycerol, resulting in immobile liquid neckings, as well as mechanical interlocking, possibly also impacted by chemical composition of the concentrates. The latter force, caused by pressure 
applied during pelleting, could delay redistributing of binding agents around the particles and the structural integrity of the pellets may change with storage duration (Pfost and Young, 1973). Related to time that is taken for redistribution of glycerol through the pellets, time related migration of water as caused by hygroscopic properties of the agent would happen and forming of liquid neckings in the inner pellet and thus hardness should increase. This is in line with our results: storage alone (unstored vs stored) led to an increase in hardness of the pellets, whereas storage duration ( 4 vs 8 weeks) did not affect hardness. This may indicate that redistribution of binding agents, or at least moisture adsorption, is not finished after cooling and before placing the pellets in storage. It is to be supposed that the lack of response of extension of storage duration on hardness is attributed to completion of redistribution of the binding agent and moisture adsorption after less than 4 weeks of storage. However, moisture equilibrium obviously was not reached within a 4-week period, because the moisture of all treatments, except the control, increased from 4 to 8 weeks of storage.

When hardness increased with decreasing pellet moisture concentrations at increasing proportions of glycerol (Table 4: unstored concentrates; glycerol of low and medium purity), total binding forces could have decreased due to a smaller amount of liquid necking. However, force per bond would then increase since water in the larger capillaries is evaporated first (Thomas and van der Poel, 1996). Subsequently, the remaining water would have established bonds between smaller particles, resulting in moister pellets being harder, as found for concentrates with glycerol of low and medium purity. On the other hand, no positive response to hardness on increasing concentrations of high-purity glycerol was observed. Hygroscopicity of glycerol should first have resulted in increased moisture concentration. However, the decrease of hardness of pellets with increasing concentration of high-purity glycerol appears to be related to moisture concentration rather than being of uniform magnitude. Despite the decrease of hardness, the proportions of fines were still similar to or even lower than those of the control, adding further evidence that glycerol positively affected physical pellet quality. When glycerol, containing $200 \mathrm{~g} / \mathrm{kg}$ water, which was very similar to the medium purity of glycerol in our study, was used for manufacturing high-fat broiler pellets and molassed pellets for fattening bulls at glycerol concentrations of $0,30,50,80$ and $100 \mathrm{~g} / \mathrm{kg}$, abrasion, i.e. the proportion of fines of total pellet mass, also decreased with increasing glycerol proportion (Löwe, 1999). When pellets were produced with molasses, however, glycerol at concentration greater than $50 \mathrm{~g} / \mathrm{kg}$ resulted in a rough and scaly surface (Löwe, 1999). This author also noted that when feeds are stored in meal form, glycerol concentration greater than $50 \mathrm{~g} / \mathrm{kg}$ may result in lump formation, and therefore suggested restricting the glycerol concentration in pelleted compound feeds to $60-70 \mathrm{~g} / \mathrm{kg}$ based on general storage behaviour including storage in large silos. 
For the majority of the stored concentrate types, hardness increased with increasing concentration of glycerol, except for the high-purity glycerol, which was already considered above. It is obvious that extent of variation of hardness is more marked for glycerol of low quality. This may be caused by the main differences between the glycerols of different purity: concentrations of water and glycerol (Table 1) differed markedly, leading to different water contents before pelleting. Although water was added to glycerols of medium and high purity and the pelleting process was adjusted intuitively based on judgement and experience of the operator, different purities of glycerol may have affected the pelleting process differently and as a result, the physical structure of the pellets might have been modified. However, differences in the pelleting process due to different composition of the concentrates are not the only causative factors for differences in physical pellet variables but also, differences in initial moisture after pelleting and cooling but before storage - could have exerted an effect due to the hygroscopicity of glycerol.

\section{CONCLUSIONS}

The concentrate without glycerol (Control) had the poorest properties in terms of durability and displayed only medium hardness values, indicating a positive effect of glycerol per se. The ability of glycerol to counteract development of undesired microbes, particularly fungi, without negatively affecting physical pellet quality, might be of particular importance for its further use. The results of this study using a limited number of quality criteria suggest that glycerol of different purity can be safely used in pelleted compound feeds in proportions up to $150 \mathrm{~g} / \mathrm{kg}$ DM. Studies using a broader range of methods and an economic assessment will expand the basis for decision-making as to the use of glycerol as a compound feed ingredient. The present data provides further support to the use of glycerol as a versatile feedstuff.

\section{ACKNOWLEDGEMENTS}

The authors are grateful to Clemens Benthin and Dr. Awadalla Ombabi for their help during pellet manufacture, and to Andrea Weßmann for skilled and never-tiring laboratory assistance. We thank Dr. G. Rave for statistical advice and helpful discussions during initial phases of this project. 


\section{REFERENCES}

Anonymous, 1970. Council Directive 70/524/EEC of 23 November 1970 Concerning Additives in Feeding-stuffs. Off. J. Eur. Union L 270, 1-17

Anonymous, 1996. Council Directive 96/25/EC of 29 April 1996 on the Circulation of Feed Materials, Amending Directives 70/524/EEC, 74/63/EEC, 82/471/EEC and 93/74/EEC and repealing Directive 77/101/EEC. Off. J. Eur. Union L 125, 35-58

Bailly J.D., Le Bars P., Pietri A., Benard G., Le Bars J., 1999. Evaluation of a fluorodensitometric method for analysis of ergosterol as a fungal marker in compound feeds. J. Food Protect. 62, 686-690

Baltes W., 1995. Lebensmittelchemie. 4th Edition. Springer Verlag, Berlin

Bassler R. (Editor), 1988, 1993. VDLUFA-Methodenbuch, Band III. Die chemische Untersuchung von Futtermitteln. 3. Auflage, 2. Ergänzungslieferung 1988 und 3. Ergänzungslieferung 1993. VDLUFA-Verlag, Darmstadt (Germany)

Brandt M., Schuldt A., Mannerkorpi P., Vearasilp T., 1987. Zur enzymatischen Stärkebestimmung im Darminhalt und Kot von Kühen mit hitzestabiler Amylase. Arch. Anim. Nutr. 37, 455

Friedrich W., 1964.ZurTechnologie des Verpressens von Mischfutter. Grundlagen, Versuchsergebnisse und ihre Bedeutung für den Mischfutterbetrieb, 2. Teil. Kraftfutter 47, 352-358

Friedrich W., Robohm K.F., 1968. Die Abriebfestigkeit von Pellets und ihre Abhängigkeit vom Pressprozess insbesondere der Kühlung. Kraftfutter 51, 20-22 and 59-64

Heiss R., Eichner K., 1994. Haltbarmachen von Lebensmitteln: Chemische, physikalische und mikrobiologische Grundlagen der Verfahren. 3rd Edition. Springer Verlag, Berlin

Körbitz W., Friedrich S., Waginger E., Wörgetter M., 2003. Worldwide Review on Biodiesel Production. Austrian Biofuels Institute, Wieselburg (Austria), pp. 121

Löwe R., 1999. Verarbeitungstechnische Konsequenzen des Einsatzes von Glycerin. Kraftfutter/ Feed Magazine 82, 394-402

Müller H.-M., Lehn C., 1988. Ergosterin als Maß für das Pilzwachstum in Futtermitteln. Arch. Anim. Nutr. 38, 227-240

Müller H.-M., Metzger K.-U., Modi R., Reimann J., 1994. Ergosterin und Fusarientoxine in Weizenkleie und Weizen. J. Anim. Physiol. Anim. Nutr. 71, 48-55

Müller H.-M., Schwadorf K., 1988. Ergosterin - ein Parameter zur quantitativen Bestimmung des Pilzbesatzes von Futtermitteln. Kraftfutter 71, 174-178

Müller H.-M., Schwadorf K., 1990. Ergosterin als Maß für das Pilzwachstum in Futtermitteln 2. Mitteilung. Ergosteringehalt von Mischfutterkomponenten und Mischfuttern. Arch. Anim. Nutr. 40, 385-395

Normenkommission für Einzelfuttermittel im Zentralausschuss der Deutschen Landwirtschaft, 2007. Positivliste für Einzelfuttermittel (Futtermittel-Ausgangserzeugnisse). 6th Edition. Zentralausschuss der Deutschen Landwirtschaft, Berlin. Available online at: http://www.futtermittel.net/ pdf/positivliste_6.pdf

Petersen U., Flachowsky G. (Editors), 2004. Workshop Positivliste für Futtermittel als Beitrag zur Futtermittelsicherheit-Erwartungen, Konzepte und Lösungen. Landbauforsch. Völkenrode Sonderheft 271, pp. 158

Pfost H.B., Young L.R., 1973. Effect of colloidal binders and other factors on pelleting. Feedstuffs 45 (49), 21-22

Roger V., Fonty G., Andre C., Gouet P., 1992. Effects of glycerol on the growth, adhesion, and cellulolytic activity of rumen cellulolytic bacteria and anaerobic fungi. Curr. Microbiol. 25, 197-201 
Rumpf H., 1958. Grundlagen und Methoden des Granulierens. Chemie-Ing.-Techn. 30, 144-158

Rumpf H., 1962. The strength of granules and agglomerates. In: W.A. Knepper (Editor). Agglomeration. John Wiley and Sons, New York, NY, pp. 379-418

SAS, 1988. STAT User's Guide. Release 6.03. SAS Institute Inc. Cary, NC

Scholz V., 1976. Methoden zur Bestimmung der mechanischen Festigkeit von Futtermittelpellets. Agrartechnik 26, 515-517

Schröder A., Südekum K.-H., 1996. Einfluss von technischem Glycerin in Mischfuttermitteln auf die Nährstoffumsetzungen in den Vormägen von Rindern. In: G. Flachowsky, J. Kamphues. (Editors). Proceedings of Workshop Unkonventionelle Futtermittel. Landbauforsch. Völkenrode Sonderheft 169, 158-162

Schröder A., Südekum K.-H., 1999. Glycerol as a by-product of biodiesel production in diets for ruminants. In: N. Wratten, P.A. Salisbury (Editors). New Horizons for an Old Crop. Proceedings of 10th International Rapeseed Congress, Canberra (Australia), Paper No. 241, p. 5 (CD-ROM). Accessible online at http://www.regional.org.au/au/gcirc/1/241.htm? PHPSESSID= 9385887f6 d09160392db2b9d241fd3fd\#P0 0

Schwadorf K., Müller H.-M., 1989. Determination of ergosterol in cereals, mixed feed components, and mixed feeds by liquid chromatography. J. Assn. Off. Anal. Chem. 72, 457-462

Siegfried R., Rückemann H., Stumpf G., 1984. Eine HPLC-Methode zur Bestimmung organischer Säuren in Silagen. Landwirtsch. Forsch. 37, 298-304

Tabil Jr. L.G., Sokhansanj S., Tyler R.T., 1997. Performance of different binders during alfalfa pelleting. Can. Agr. Eng. 39, 17-23

Thomas M., van der Poel A.F.B., 1996. Physical quality of pelleted animal feed 1. Criteria for pellet quality. Anim. Feed Sci. Tech. 61, 89-112

Thomas M., van Vliet T., van der Poel A.F.B., 1998. Physical quality of pelleted animal feed 3. Contribution of feedstuff components. Anim. Feed Sci. Tech. 70, 59-78

Thomas M., van Zuilichem D.J., van der Poel A.F.B., 1997. Physical quality of pelleted animal feed. 2. Contribution of processes and its conditions. Anim. Feed Sci. Tech. 64, 173-192 